\title{
Effects of elevated temperature and carbon dioxide on food consumption and growh of Spodoptera litura Fabricius on cauliflower
}

\author{
SMRITI SHARMA and TEJINDER SINGH BRAR \\ Department of Entomology, Punjab Agricultural University, Ludhiana- 141 004, India \\ *Corresponding author Email: smritisharma80@pau.edu
}

\begin{abstract}
The studies on influence of temperature and carbon dioxide levels on food consumption and growth of Spodoptera litura on cauliflower were conducted in controlled environment during 2015-16 with two different temperature $\left(25: 11^{\circ} \mathrm{C}\right.$ and $\left.25: 14^{\circ} \mathrm{C}\right)$ and three carbon dioxide regimes $(350,400,450$ $\mathrm{ppm}$ ). Temperature and carbon dioxide had significant effect on food consumption parameters of $S$. litura.Overall the food consumption of $S$. litura increased from $0.18 \mathrm{~g} \mathrm{larva}^{-1}$ at temperature of $25: 11^{\circ} \mathrm{C}$ and $\mathrm{CO}_{2}$ of $350 \mathrm{ppm}$ to $0.31 \mathrm{~g} \mathrm{larva}^{-1}$ at temperature of $25: 14^{\circ} \mathrm{C}$ and $\mathrm{CO}_{2}$ of $450 \mathrm{ppm}$. Similarly, relative growth rate increased from 0.15 to $0.27 \mathrm{mg} \mathrm{mg}^{-1}$ day $^{-1}$ and larval weight gain increased from 0.14 to 0.28 gday ${ }^{-1}$. However, with increase in $\mathrm{CO}_{2}$ concentration at $450 \mathrm{ppm}$, the larval weight gain decreased from 0.28 to $0.22 \mathrm{~g} \mathrm{day}^{-1}$.
\end{abstract}

Keywords: Spodoptera litura, nutritional indices, temperature, carbon dioxide, cauliflower.

Insects play significant roles as herbivores, pollinators, predators and parasitoids and any change in their abundance and diversity has the potential to alter the functioning of any ecosystem (Hillstrom and Lindroth, 2008). Global warming, resulting from increased level of $\mathrm{CO}_{2}$, could cause qualitative and quantitative changes in the agricultural, horticultural and forest plants that would alter the abundance and distribution pattern of insect pest species (Kiritani, 2006). Temperature has a direct effect on development of insects, but elevated carbon dioxide $\left(\mathrm{eCO}_{2}\right)$ has an indirect and host- mediated effects (Yadugiri, 2010). It has been reported that Lepidopteran species, that feed on eCO2grown foliage are likely to have decreased fitness, higher mortality, decreased larval weight and prolonged development times (Yin et al. 2010). Most published studies on response of insect herbivores to elevated temperature and $\mathrm{CO}_{2}$ conditions had focused on short term feeding experiments (Bezemer and Jones, 1998), with majority of these dealing with individual effects of elevated $\mathrm{CO}_{2}$ or temperature. But, these abiotic components do not exert independent effects on herbivores (Whittaker, 1999) due to the fact that rising atmospheric $\mathrm{CO}_{2}$ concentrations would consequently increase the temperature (Thompson, 1989) hence, their interaction should be considered for a holistic approach.The tobacco caterpillar, Spodoptera litura Fabricius (Lepidoptera: Noctuidae) is polyphagous pest, damaging many economically important vegetables and ornamental plants and has a huge potential to invade new areas by adapting to wide range of ecological situations. The temperature rise of $2.7-4.7^{\circ} \mathrm{C}$ predicted due to potential climate change may have drastic consequences for future incidence of S. litura (IPCC, 2013). Studies by Fand et al. (2015) revealed that the development rate of $S$. litura increased linearly for all the immature stages until at 34 $36^{\circ} \mathrm{C}$. The results demonstrated the importance of optimum temperature in determining the suitability of climate for reproduction in $S$. litura.Hence present study aimed to understand the effect of elevated concentrations of $\mathrm{CO}_{2}$ coupled with alternating temperature conditions on nutritional indices of $S$. litura on cauliflower.

\section{MATERIALS AND METHODS}

An experiment was carried out during 2015-16 in Controlled Environment Chamber (PGW-40, M/s Percival Scientific, Inc., USA), at Department of Entomology, Punjab Agricultural University, Ludhiana to study the effect of temperature and carbon dioxide regimes on the food consumption and growth rate of $S$. litura.

\section{Rearing of the test insect}

The initial culture of S. litura was collected from cabbage and cauliflower fields and reared in jars under laboratory conditions. These larvae were fed withfresh and cleaned cauliflower leaves as per the methodology given by Pandey et al. (2015). The insect culture was maintained throughout the study period to get continuous supply of sufficient number of insects. The glassware used in the experiments was thoroughly washed in detergent, treated 
with 2 per cent formalin and then dried in an oven at $30^{\circ} \mathrm{C}$ for 8 hours to check microbial contamination in the insect culture.

The treatments were comprised of temperature and carbon dioxide combinations as given below

\begin{tabular}{llll}
\hline $\begin{array}{l}\text { Temperature }\left({ }^{\circ} \mathrm{C}\right) \\
\mathrm{T}_{\text {max }}: \mathrm{T}_{\text {min }}\end{array}$ & $\begin{array}{l}\mathrm{CO}_{2} \\
\text { concentration } \\
(\mathrm{ppm})\end{array}$ & $\begin{array}{l}\text { Photoperiod } \\
\text { (h) } \\
\text { Light:Dark }\end{array}$ & $\begin{array}{l}\text { Relative } \\
\text { humidity } \\
(\%)\end{array}$ \\
\hline (i) $25: 11$ & (i) 350 & $14: 10$ & $65 \pm 5$ \\
(ii) $25: 14$ & $\begin{array}{l}\text { (ii) } 400 \\
\text { (iii) } 450\end{array}$ & & \\
\hline
\end{tabular}

\section{Food consumption}

The data on food consumption, nutritional indices and growth indices were calculated on S. litura from third to fifth instars using cauliflower leaves as food. The experiment on feeding of larvae was performed in 4 replications. Each replication consisted of 25 larvae at each temperature and $\mathrm{CO}_{2}$ condition, kept singly in plastic sample containers to avoid over crowding and congestion. Holes were made in lid of containers for aeration. Initial weight of each larva was recorded before the start of experiment. Before offering leaves as food to larva, the weight of larva and leaf were measured and then after 24 hours, weight of remaining leaf, larval weight and faecal matter was recorded. The leaves were provided to larvae until pupation. The data on weight of larva, food, faeces and pupa was recorded on electronic balance with a sensitivity of $0.1 \mathrm{mg}$. Under each condition, a set of control leaves was also kept and weighed every day to ascertain the moisture loss of leaves to calculate the actual weight of food eaten by larvae. A set of additional larvae were maintained under each temperature $\mathrm{CO}_{2}$ conditions in similar way. Whenever any of the test larvae died, a larva from the additional set was added to replace it so that number of larvae in each replication remains same.

\section{Nutritional and growth indices}

Data on larval weight (g), faecal matter (g), fresh food and uneaten food $(\mathrm{g})$ was recorded daily and weight gained (g) was utilized to work out various nutritional indices on fresh weight basis according to Waldbauer (1968). Relative growth rate and larval weight gainwerealso calculated to ascertain the effect of elevated temperature and $\mathrm{CO}_{2}$ on growth and food utilization by $S$. litura on cauliflower.Food consumption and relative growth rate (RGR) were calculated for third to fifth instar larvae (Waldbauer, 1968).

\section{Statistical analysis}

Mean and standard error was calculated from the data under each head and data was analyzed for analysis of variance with two factor Factorial Completely Randomized Design (CRD) using computer software CPCS 1 (Cheema and Singh, 1993).

\section{RESULTS AND DISCUSSION}

\section{Food consumption by $S$. lituralarvae}

Mean food consumption by third, fourth and fifth instar larvae was observed to increase with increase in temperature from 11 to $14^{\circ} \mathrm{C}$, and with $\mathrm{CO}_{2}$ concentration from 350 to 400 and $450 \mathrm{ppm}$ (Table 1). Temperature showed a significant effect on food consumption with highest mean food consumption $\left(\mathrm{g} \mathrm{larva}^{-1}\right)$ by fifth $(0.36)$ followed by fourth (0.23) and third instars (0.20). Carbon dioxide also showed a significant effect on food consumption with highest mean food consumption ( $\mathrm{g}_{\text {larva }} \mathrm{a}^{-1}$ ) by fifth instar larva $(0.39)$ followed by fourth (0.27) and third (0.24) instars at $450 \mathrm{ppm}$ $\mathrm{CO}_{2}$ concentration. Highest interactive effect of temperature and carbon dioxide was observed in third and fifth instars at temperature $25: 14^{\circ} \mathrm{C}$ and carbon dioxide $450 \mathrm{ppm}$ combinations. Maximum per cent increase over previous instar was observed in case of fifth instar larvae (45.45) at $25: 14^{\circ} \mathrm{C}$ temperature and $350 \mathrm{ppm}$ carbon dioxide concentration whereas lowest per cent increase was observed in fourth instar larvae (5.88) at $25: 11^{\circ} \mathrm{C}$ and $350 \mathrm{ppm}$ carbon dioxide concentration. Present studies are similar to those reported by Pandey et al.(2015) who reported that food consumption of $H$. armigera increased with increase in temperature. Khadar et al.(2014) also reported that food consumption by $H$. armigera increased by 81.6 per cent under elevated $\mathrm{CO}_{2}$ conditions as compared to ambient conditions. Similar results were observed by Dalal and Arora (2016) who also observed that food consumption by $H$. armigera increased with increase in temperature. It has been reported that with increase in $\mathrm{CO}_{2}$ concentration and with increase in minimum temperature the food consumption by S. litura larvae increases which might be due to the reduction in protein content and increase of $\mathrm{C} / \mathrm{N}$ ratio in leaves under elevated $\mathrm{CO}_{2}$ (Hunter, 2001).

\section{Relative growth rate}

The data on relative growth rate (RGR, $\mathrm{mg} \mathrm{mg}^{-1}$ day $\left.^{-1}\right)$ of S. litura larvae from third to fifth instars at different alternating temperatures and carbon dioxide are presented in Table 2. The overall mean RGR of 350, 400 and 450 ppm 


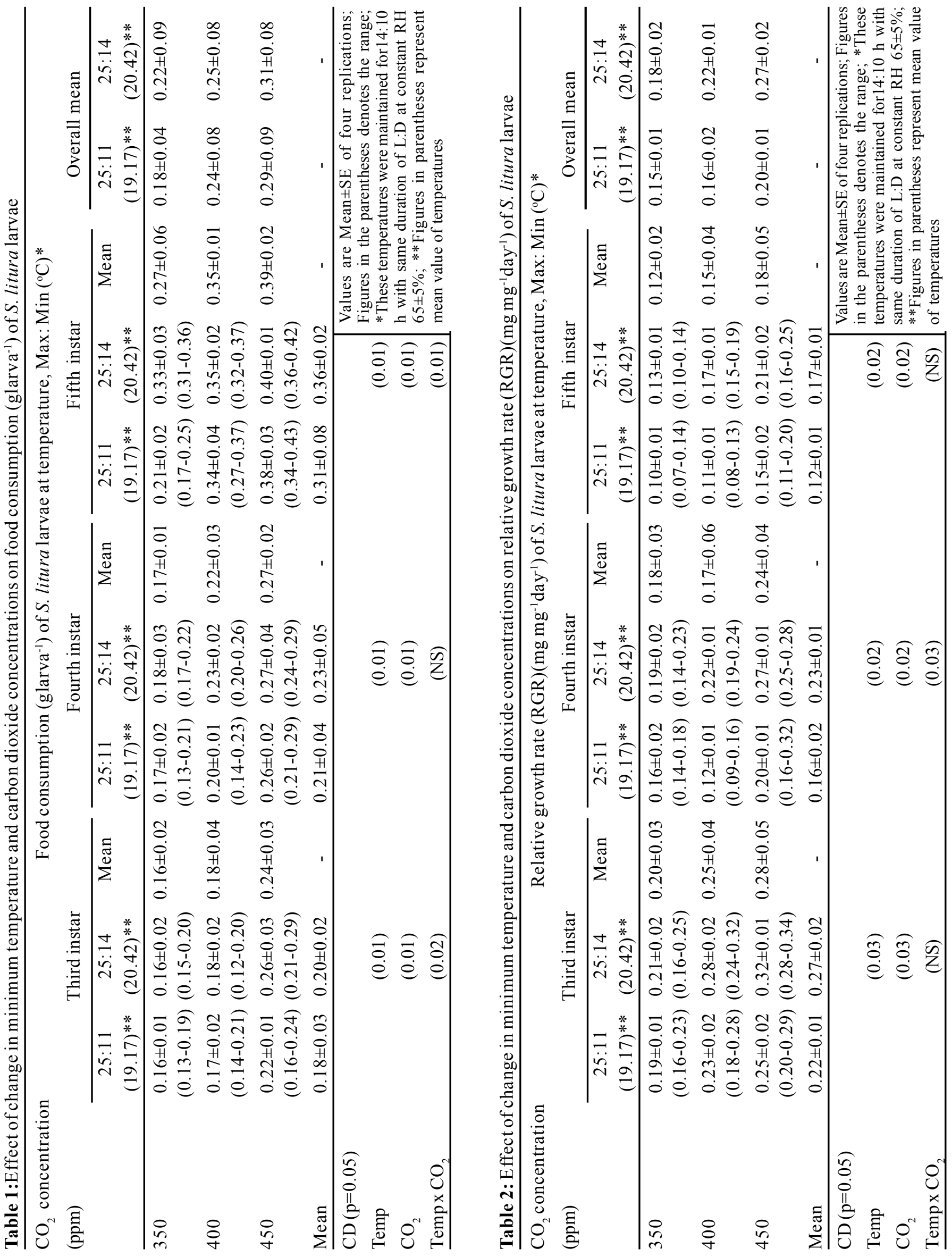


was recorded to be $0.15,0.15$ and $0.20 \mathrm{mg} \mathrm{mg}^{-1} \mathrm{day}^{-1}$, respectively at $25: 11^{\circ} \mathrm{C}$ whereas at $25: 14^{\circ} \mathrm{C}$ the mean $R G R$ values was recorded to be $0.18,0.22$ and $0.27 \mathrm{mg} \mathrm{mg}^{-1}$ day $^{-1}$ of 350,400 and $450 \mathrm{ppm} \mathrm{CO}_{2}$ concentration, respectively. It was found that temperature had a significant effect on RGR of third fourth and fifth instars. The RGR was highest in the third instar, and lowest in the fifth instar with intermediate values in the fourth instar at the two alternating temperatures. The highest values of mean RGR of third, fourth and fifth were observed to be $0.27,0.23$ and $0.17 \mathrm{mg}$ $\mathrm{mg}^{-1}$ day $^{-1}$, respectively at $25: 14^{\circ} \mathrm{C}$ irrespective of the carbon dioxide concentration. Carbon dioxide also had significant effect on third, fourth and fifth instars. Highest RGR values of third, fourth and fifth instars $(0.28,0.24$ and 0.18 , respectively) were observed at $450 \mathrm{ppm}$ concentration of carbon dioxide. The interactive effect of temperature and carbon dioxide was observed to be insignificant in third and fifth instars larvae whereas these factors showed significant effect on fourth instar larvae with highest RGR value (0.27) at $25: 14^{\circ} \mathrm{C}$ and $450 \mathrm{ppm}$ carbon dioxide combination. The per cent increase in RGR with an increase in minimum temperature of $3^{\circ} \mathrm{C}$ from 11 to $14^{\circ} \mathrm{C}$ was recorded to be 29.95. Also per cent increase from 350 to $400 \mathrm{ppm}, 400$ to $450 \mathrm{ppm}$ and 350 to $450 \mathrm{ppm}$ was recorded to be 12.12 , 27.02 and 42.42 , respectively. These results are similar to those reported by Dalal and Arora (2016) that the RGR of $H$. armigera increased with increase in temperature. These results are in contrast with those reported by Rao et al.(2012) that RGR of S. litura decreased when feed on peanut foliage under elevated $\mathrm{CO}_{2}$ conditions which may be because of effect of elevated $\mathrm{CO}_{2}$ on host and its effect on insect, while in our case this increase in RGR is due to the effect of elevated temperature and $\mathrm{CO}_{2}$ on $\mathrm{S}$. litura larvae and there are no host mediated effects.

\section{Larval weight gain}

The data on mean larval weight gain $\left(\mathrm{g} \mathrm{day}^{-1}\right)$ of $S$. litura larvae from third to fifth instars at different alternating temperatures and $\mathrm{CO}_{2}$ are presented in Table 3. Mean larval weight gain of third instar larvae was recorded to be 0.28 , 0.33 at $25: 11^{\circ} \mathrm{C}$ and $25: 14^{\circ} \mathrm{C}$, respectively and $0.26,0.33$ and $0.32 \mathrm{~g} \mathrm{day}^{-1}$ at $\mathrm{CO}_{2}$ concentration of 350,400 and 450 $\mathrm{ppm}$, respectively. Mean larval weight gain $\left(\mathrm{g} \mathrm{day}^{-1}\right)$ of fifth instar larvae was recorded to be $0.10,0.20$ at $25: 11^{\circ} \mathrm{C}$ and $25: 14^{\circ} \mathrm{C}$, respectively and $0.07,0.18$ and 0.11 at $\mathrm{CO}_{2}$ concentration of 350,400 and $450 \mathrm{ppm}$, respectively. The overall mean larval weight gain $\left(\mathrm{g} \mathrm{day}^{-1}\right)$ of 350,400 and 450 ppm was recorded to be $0.14,0.23$ and 0.17 , respectively at 
$25: 11^{\circ} \mathrm{C}$ whereas at $25: 14^{\circ} \mathrm{C}$ the mean larval weight gain was recorded to be $0.20,0.28$ and $0.22 \mathrm{~g} \mathrm{day}^{-1}$ of 350,400 and $450 \mathrm{ppm} \mathrm{CO}_{2}$ concentration, respectively. It was found that temperature and $\mathrm{CO}_{2}$ had a significant effect on larval weight gain in these three instars. The interactive effect of temperature and carbon dioxide was observed to be insignificant in third and fourth instars larvae whereas interaction of temperature and carbon dioxide showed significant effect on fifth instar larvae with highest value of $0.20 \mathrm{~g} \mathrm{day}^{-1}$ at $25: 14^{\circ} \mathrm{C}$ and $450 \mathrm{ppm} \mathrm{CO}_{2}$. It was observed that maximum weight gain was recorded at ambient $\mathrm{CO}_{2}$ conditions but with any increase or decrease in $\mathrm{CO}_{2}$ concentration, the weight gain of larvae decreased. On the contrary, with increase in minimum temperature the weight gain of $S$. litura larvae increased. These results are contrary to the findings of Rao et al. (2012) who reported higher larval weight in $550 \mathrm{ppm}(18 \%)$ and $700 \mathrm{ppm}(32 \%) \mathrm{CO}_{2}$ conditions, which could be attributed to higher RCR values in their studies. As earlier stated, the results in present study are effects of elevated $\mathrm{CO}_{2}$ and temperature on insect and no indirect effects though host have affected S. litura larvae. Similarly, Khadar et al. (2014) reported that inspite of increase of food consumption, RCR and AD; the gain in larval weight was nearly 4.4 per cent over ambient conditions. This could be attributed to lower protein content and higher carbon content in plant tissues thus reducing the efficiency of conservation of ingested food and digested food. Temperature has been generally considered the single most significant environmental factor influencing behaviour, distribution, development, survival and reproduction in insects (Bale et al. 2002). It was observed that under elevated temperature and $\mathrm{CO}_{2}$ conditions increased herbivory and ultimately higher crop damage could be observed, but decreased larval weight gain and relative consumption rate indicate smaller larvae and affected development. These results could lead to an improved understanding of the field dynamics and the activity of $S$. litura under elevated temperature and $\mathrm{CO}_{2}$ conditions. Further studies on more detailed insights are required to quantify these effects and predicting the damage potential under climate change scenario.

\section{CONCLUSION}

It can be concluded that food consumption, relative growth rate and larval weight gain increased with increase in minimum temperature by $3^{\circ} \mathrm{C}$. These parameters also increased with increase in carbon dioxide concentration from 350 to $450 \mathrm{ppm}$.It can be concluded that minimum temperature, carbon dioxide and their interactive effect influences the nutritional and growth indices of S. litura.

\section{ACKNOWLEDGMENTS}

The authors are thankful to Head, Department of Entomology, Punjab Agricultural University, Ludhiana and Department of Science and Technology (DST), Government of India for providing financial assistance and equipments under Promotion of University Research and Scientific Excellence (PURSE) grant to conduct the research work.

\section{REFERENCES}

Bale, J., Masters, G.J., Hodkins, I.D.,Awmack, C., Bezemer, T.M., Brown, V.K., Butterfield, J.,Buse, A., Coulson, J.C., Farrar, J., Good, J.E.G., Harrington, R., Hartley, S., Jones, T. H., Lindroth, R. L., Press, M.C., Symrnioudis, I., Watt, A. D. and Whittaker, J.B. (2002). Herbivory in global climate change research: direct effects of rising temperature on insect herbivores. Global Change Biol. 8: $1-16$.

Bezemer, T.M. and Jones, T.H.(1998). Plant-insect herbivore interactions in elevated atmospheric $\mathrm{CO}_{2}$ Quantitative analysis and guild effects. Oikos, 82:212-222.

Cheema, H.S. and Singh, B.(1993). CPSC1: a programme package forthe analysis of commonlyused experimental designs. Punjab Agricultural University, Ludhiana, Punjab.

Dalal, P.K. and Arora,R. (2016).Impact of temperature on food consumption and nutritional indices of tomato fruit borer, Helicoverpa armigera (Hübner) (Noctuidae: Lepidoptera). J.Agrometeorol.,18(1): 62-67.

Fand, B.B., Sul, N.T., Bal, S.K. and Minhas, P. S. (2015). Temperature Impacts the Development and Survival of Common Cutworm (Spodoptera litura): Simulation and Visualization of Potential Population Growth in India under Warmer Temperatures through Life Cycle Modelling and Spatial Mapping. PLoS ONE, 10(4): e0124682. doi:10.1371/journal.pone.0124682

Hillstrom, M.L. and Lindroth, R.L.(2008).Elevated atmospheric carbon dioxide and ozone alter forest insect abundance and community composition. Insect Conser. Div., 1: 233-241.

Hunter, M.D.(2001). Effects of elevated atmospheric carbon dioxide on insect-plant interactions. Agric. For.Ent., 3: 153-159. 
IPCC. (2013). The physical science basis. Summary for policy makers, Contribution of working group one to fifth assessment report of the intergovernmental panel on climate change.pp. 3 IPCC, WMO, Geneva, Switzerland.

Khadar, A.B., Prabhuraj, A., Rao,M.S., Sreenivas,A.G. and Naganagoud, A.(2014). Influence of elevated $\mathrm{CO}_{2}$ associated with chickpea on growth performance of gram caterpillar, Helicoverpa armigera (Hüb.). Appl. Ecol. Environ. Res.12: 345-353.

Kiritani, K.(2006). Predicting impacts of global warming on population dynamics and distribution of arthropods in Japan. Pop. Ecol.,48: 5-12.

Pandey, S., Sharma, S., Sandhu, S.S. and Arora, R. (2015). Development and food consumption of some lepidopteran pests under increased temperature conditions. J.Agrometeorol., 17(1): 36-42.

Rao, M.S.,Manimanjari,D., Vanaja,M.,RamaRao, C.A., Srinivas, K.,Rao V.U.M.and Venkateswarlu,B.(2012). Impact of elevated $\mathrm{CO}_{2}$ on tobacco caterpillar, Spodopteralitura on peanut, Arachnis hypogea. J. Insect Sci., 12: 103106.

Thompson, R.D.(1989).Short-term climatic change: evidence, causes, environmental consequences and strategies for action. http://journals.sagepub.com/doi/pdf/10.1177/ 03091333890130030.1 .

Waldbauer, G.P. (1968). The consumption and utilization of food by insects. Adv. Insect Physiol.,5: 229-282.

Whittaker, J.B.(1999). Impacts and responses at population level of herbivorous insects to elevated $\mathrm{CO}_{2}$. Eur.J.Ent., 96: $149-146$.

Yadugiri, V. T.(2010). Climate change: the role of plant physiology. Curr. Sci., 99: 423-425.

Yin, J., Sun, Y., Wu G. and Ge,F. (2010). Effects of elevated $\mathrm{CO}_{2}$ associated with maize on multiple generations of the cotton bollworm, Helicoverpaarmigera.Ent. Exp. Appl., 136:123-120. 